Pre-print of Agnew et al (2011)

Full version published in Journal of Hazardous Materials, Volume 186, pages 1405-1414 


\title{
Electrokinetic remediation of plutonium-contaminated nuclear site wastes: results from a pilot-scale on-site trial.
}

Kieran Agnew ${ }^{1}$, Andrew B. Cundy ${ }^{2}$, Laurence Hopkinson ${ }^{2}$, Ian W. Croudace ${ }^{3}$, Phillip E. Warwick ${ }^{3}$, and Philip Purdie ${ }^{1}$

1. AWE PLC, Aldermaston, Berks, RG7 4PR, U.K.

2. School of Environment and Technology, University of Brighton, Lewes Road, Brighton, BN2 4GJ, U.K.

3. GAU-Radioanalytical Laboratories, School of Ocean \& Earth Science, National Oceanography Centre, European Way, Southampton, SO14 3ZH, U.K.

* Corresponding author. Tel: +44 1273 642270; Fax: +44 1273 642285; Email:

A.Cundy@brighton.ac.uk

\begin{abstract}
.
This paper examines the field-scale application of a novel low-energy electrokinetic technique for the remediation of plutonium-contaminated nuclear site soils, using soil wastes from the Atomic Weapons Establishment (AWE) Aldermaston site, Berkshire, U.K. as a test medium. Soils and sediments with varying composition, contaminated with $\mathrm{Pu}$ through historical site operations, were electrokinetically treated at laboratory-scale with and without various soil pre-conditioning agents. Results from these bench-scale trials were used to inform a larger on-site remediation trial, using an adapted containment pack with battery power supply. $2.4 \mathrm{~m}^{3}$ ( $c a .4$ tonnes) of Pu-contaminated soil was treated for 60 days at a power consumption of $33 \mathrm{kWh} / \mathrm{m}^{3}$, and then destructively sampled. Radiochemical data indicate mobilisation of $\mathrm{Pu}$ in the treated soil, and migration (probably as a negatively charged Pu-citrate complex) towards the anodic compartment of the treatment cell. Soil in the cathodic zone of the treatment unit was remediated to a level below free-release disposal thresholds $(1.7 \mathrm{~Bq} / \mathrm{g}$, or $<0.4$ $\mathrm{Bq} / \mathrm{g}$ above background activities). The data show the potential of this method as a low-cost, on-site tool for remediation of radioactively-contaminated soils and wastes which can be operated remotely on working sites, with minimal disruption to site infrastructure or operations.
\end{abstract}

\section{Keywords.}

Land remediation; electrokinetic; plutonium; contaminated land; on-site trial. 


\section{Introduction.}

One of the major environmental legacies of military and civil nuclear activities has been the generation of areas of land contaminated with anthropogenic radionuclides, due to authorised/licensed or accidental discharge. Due to the long half-lives of many of these radionuclides, the presence of radioactively contaminated soils around nuclear sites presents a long-term environmental concern and may constrain the extent to which sites can be redeveloped and re-used following decommissioning. In addition, groundwater contamination by more soluble radioactive species may be a significant problem. Consequently considerable research and financial effort has been expended on developing methods which can be used to remediate or stabilise radioactively contaminated soils and sediments. In the U.K., depending on the level of radioactivity in the contaminated soil, waste soils have typically been disposed of to the UK's low-level waste repository (LLWR) in Cumbria. However, given the expense of disposal (> $£ 1000$ per $\mathrm{m}^{3}$ ), disposal restrictions, and a perceived need to find more sustainable waste management solutions (e.g. [1]), there has recently been considerable interest both in the UK and internationally in a range of in-situ and ex-situ remediation technologies for radioactivelycontaminated soil and groundwater, including phytoremediation (often with application of soil preconditioning solutions [2,3]), stabilisation [4], and soil washing or leaching [5,6].

While these technologies have been applied in a range of environments, their application in clay- and silt-rich soils may be problematic, due largely to the low hydraulic conductivities of these soils. One emerging technology that has, however, received much attention as a practical in-situ remediation technology for low permeability clay-rich soils is electrokinetic remediation. Electrokinetics is a process that separates and extracts organic, inorganic, and radioactive contaminants from saturated or unsaturated clay-rich soils, sludges and sediments under the influence of an applied electrical field. Electrokinetic remediation methods have been successfully employed at laboratory scale on a range of radioactively-contaminated materials (e.g. [7-9]), and at full field-scale for a variety of metallic and organic contaminants [10,11]. The electrokinetically-driven containment of radioactivelycontaminated groundwater has also been discussed [9]. Despite promising laboratory results, however, the field-scale application of electrokinetic remediation to radioactively-contaminated soils remains poorly developed. Here, the application of a low-energy electrokinetic technology to the remediation of Pu-contaminated nuclear site soils is examined, using soil wastes from the Atomic Weapons Establishment (AWE) Aldermaston site, Berkshire, U.K. as a test medium. Results from a large-scale field pilot study are presented, and the implications for remediation (and storage) of nuclear site wastes assessed. 


\section{Study area - AWE Aldermaston.}

The Atomic Weapons Establishment (AWE) at Aldermaston (Berkshire, U.K.) has manufactured and maintained the warheads for the U.K.'s nuclear deterrent for more than 50 years. The Aldermaston site lies on a former World War II airfield, built on Quaternary plateau gravels underlain by Tertiary sands and gravels of the Lower Bagshot Beds. These in turn rest on a layer of London Clay (of several tens of meters thickness), which acts as a barrier to groundwater flow from the site into the underlying Chalk aquifer. Nuclear weapons manufacture and maintenance, and related research and development activities, have produced small amounts of radioactive (principally plutonium, tritium and uraniumcontaining), heavy metal and organic chemical wastes. These were processed and disposed of, in accordance with contemporary handling and disposal practices, to the local environment. Historical disposal practices that were considered acceptable at the time have subsequently generated a number of contaminated land legacy issues, involving hydrocarbon, trichloromethane, trichloroethene, mercury, tritium and plutonium contamination [12]. In terms of radionuclides, whilst the site is radiologically safe, soil in a few locations contains above-background specific activities of plutonium arising from historical operations. Previous work at the site has indicated that the plutonium present is strongly sorbed to soils/sediments, with little re-dissolution $\left(\mathrm{K}_{\mathrm{d}}\right.$ values range between $2 \times 10^{6}$ and $6 \mathrm{x}$ $\left.10^{6}[13]\right)$. Much of the plutonium-labelled soil has been removed (via soil excavation) and is held in containment units on site, prior to remediation / decommissioning.

\section{Experimental}

\subsection{Background: low-energy electrokinetic remediation.}

The experiments described here utilise a low energy, non-selective, low cost electrokinetic remediation process known as the FIRS technique (Ferric Iron Remediation and Stabilisation [14], figure 1). This process involves the application of a low magnitude (typically less than $0.2 \mathrm{~V} / \mathrm{cm}$ ) direct electric potential between two or more iron-rich electrodes emplaced in a contaminated soil or sediment. The electric potential is used to generate a strong $\mathrm{pH} / \mathrm{Eh}$ gradient within the soil column. This remobilises contaminants from the soil and (following partial dissolution of the sacrificial anode electrode(s)), may force the precipitation of an iron- (and manganese-) rich barrier or "wall" in the soil between the electrodes at the boundary of the acid and alkaline zones (figure 1). This Fe-rich "wall" acts as a chemical and physical barrier to contaminant migration $[14,15]$. The contaminants which are remobilised by the acid or alkaline conditions generated by the technique are, depending on their physicochemical behaviour, either precipitated at (or around) the $\mathrm{pH} / \mathrm{Eh}$ "jump" in the cell, sorbed onto the $\mathrm{Fe}$ (and $\mathrm{Mn}$ ) mineral phases precipitated in the Fe-rich barrier, forced to migrate towards the appropriately charged electrode, or washed from the cell by electro-osmotic flow (figure 1, $[14,16]$ ). 
Alternatively, the system can be used to supply iron to a contaminated soil mass as a reducing (and stabilising) agent for redox-sensitive contaminants such as $\mathrm{Cr}(\mathrm{VI})$ and $\mathrm{Tc}$ (e.g. [17,18]). At the applied voltages and currents used $(<0.1 \mathrm{~A}$ in clay-rich sediments and soils), the system has less than a tenth of the energy requirements of conventional electrokinetic systems [14].

\subsection{Laboratory proof of concept and optimisation trials.}

\subsubsection{Experimental methods}

Samples of historically-contaminated AWE Aldermaston site soil (held in storage at the National Oceanography Centre, Southampton, U.K.) from three different source areas (designated as type 1, type 2 and type 3 soils in Table 1) were transferred to a plastic mixing vessel, moistened with groundwater (retrieved from boreholes at the AWE Aldermaston site), and hand-mixed for 30 minutes to ensure a homogenous bulk starting material. Soil sub-samples of approximately $4 \mathrm{~kg}$ (wet weight) were packed into containers measuring $22 \mathrm{~cm}$ x $15 \mathrm{~cm}$ x $13 \mathrm{~cm}$. Small sample volumes $\left(<0.004 \mathrm{~m}^{3}\right.$ per treatment cell) were used to minimise risk from handling of radioactively-contaminated material, and to minimise volumes of waste material requiring shipment and disposal following laboratory trials. A pair of machined cast iron electrodes, $20 \mathrm{~cm}$ long and $1 \mathrm{~cm}$ in diameter, were centred and inserted vertically into sand wells (using fine acid washed sand, to facilitate drainage of water and prevent sample desiccation) at the edges of the soil mass in each container at an electrode separation of $16 \mathrm{~cm}$. The electrodes were connected to a power supply and 20V (direct current) applied across each cell for a period of 50 days, in order to examine the application of the electrokinetic process to the range of plutonium-contaminated soil wastes currently held on-site by AWE PLC. All soils contained a mixture of clay minerals (illite and smectite), comminuted flint, and chalk and ignitable (organic) content. Current and $\mathrm{pH}$ (determined using a Hanna Instruments $\mathrm{Ph} 213$ microprocessor $\mathrm{pH}$ probe) were monitored periodically throughout the duration of the experiment and water added to the anode zone at a rate of $2 \mathrm{ml}$ per day to prevent soil desiccation. After 50 days, non-destructive X-ray fluorescence scanning (ITRAX) was employed to rapidly examine major and trace element redistribution at high spatial resolution. Subsequently, the cells were destructively sampled for gamma spectrometry, radiochemical analysis and quantitative wavelength dispersive XRF (WDXRF). Details of the analytical characterisation methods used are given in section 3.2.2.

The above trials were repeated using samples of the soil material (type 3) to be tested at field scale, to examine the effect of soil pore-water ionic strength and the application of soil pre-conditioning agents on the electrokinetic remediation process. In order to facilitate testing of multiple samples, a revised experimental design was applied. Soil samples were wetted with: (a) groundwater sourced from 
boreholes on the AWE Aldermaston site; (b) sterilised seawater (collected from the Solent, southern England); and (c) 30\% citric acid solution; then loaded (as a slurry) into silicone tubes (45cm long, $12 \mathrm{~mm}$ internal diameter). A voltage of $19.2 \mathrm{~V}$ was then applied for 32 days across small $(<4 \mathrm{~cm}$ length) iron electrodes inserted at each end of the tube. Samples were also run in $20 \mathrm{~cm}$ long $(35 \mathrm{~mm}$ internal diameter) acrylic tubes, to facilitate elemental profiling of major and trace element (re)distribution.

\subsubsection{Analytical techniques.}

Treated sediments were frozen, and then sliced along the long axis of the treatment cell to provide a clean surface for ITRAX analysis [19]. The advantage of using the ITRAX (a micro-XRF system that uses a $200 \mu \mathrm{m} \times 20 \mathrm{~mm}$ capillary waveguide) is that it can analyse large samples (up to $120 \mathrm{x} 1800 \mathrm{~mm}$ ) rapidly, non-destructively and at high spatial resolution. Samples only require an approximately flat surface and can be analysed in air. The X-ray beam is produced using a $3 \mathrm{~kW}$ Mo X-ray tube operating at $30 \mathrm{kV}$ and $30 \mathrm{~mA}$. XRF spectra are typically acquired for 30 seconds at every incremental position before the sample moves under software control to the next position. The X-ray spectra are analysed using the proprietary software QSpec provided with the ITRAX system; outputs are elemental peak areas which have been demonstrated to reflect element abundances.

Following initial ITRAX investigation each cell was then further sub-sampled via removal of soil at discrete intervals away from the cathode electrode. Soil samples were dried at $105^{\circ} \mathrm{C}$ prior to analysis of plutonium, gamma-emitting radionuclides and elemental composition via WDXRF. Plutonium activities were determined using an established method [20] involving spiking each sample with a traceable ${ }^{242} \mathrm{Pu}$ solution, an aqua regia leach, anion exchange chromatography and electroplating. Alpha spectrometry, using Ortec Octete alpha spectrometers (Wokingham, UK), was used to count the

alpha emissions from the electroplated samples, and ${ }^{239+240} \mathrm{Pu}$ and ${ }^{238} \mathrm{Pu}$ activities determined relative to a ${ }^{242} \mathrm{Pu}$ spike. Activities of gamma-emitting radionuclides were measured using Canberra HPGe well detectors and Fitzpeaks Gamma Analysis software (JF Computing, Stanford in the Vale, UK). Gross alpha and beta activities were determined, for screening purposes, on ground $125 \mathrm{mg}$ samples counted in planchettes using a Tennelec XLB gas flow proportional counter (calibrated using ${ }^{241} \mathrm{Am}$ and ${ }^{137} \mathrm{Cs}$ ). A Philips MAGIX-Pro WDXRF spectrometer (with 4kW Rh end window X-ray tube) was used to determine quantitative elemental compositions from pressed powder pellets. Calibration lines for all elements were determined using a suite of international reference samples. SuperQ software was used to apply inter-element corrections based on fundamental parameter algorithms and the scattered radiation method. The WDXRF technique [21] provides typical detection limits of 1-2 ppm for many trace elements ( $\mathrm{Rb}, \mathrm{Sr}, \mathrm{Y}, \mathrm{Zr}, \mathrm{Nb}, \mathrm{Th}, \mathrm{Zn}, \mathrm{Ni}, \mathrm{As}, \mathrm{Pb}, \mathrm{U})$, through to 10ppm for others (e.g. $\mathrm{Cr}, \mathrm{V}, \mathrm{Ce})$. 


\subsection{On-site pilot trial}

The plutonium-labelled site soils had been stored in weather-proofed but unsealed containment units on-site for $c a .10$ years, resulting in drying and desiccation of the soil material. To homogenise and rehydrate the soils prior to electrokinetic treatment, approx. 4 tonnes $\left(2.4 \mathrm{~m}^{3}\right)$ of soil (soil type 3 , Table 1) was disaggregated by passing through a scaffolding mesh $(c a .10 \mathrm{~cm}$ mesh size) into a lined treatment cell (i.e. a metal containment unit, lined with plastic sheeting), and saturated using $0.04 \mathrm{M}$ citric acid dissolved in local groundwater (figure 2). Ten steel electrodes (70 $\mathrm{cm}$ long, $20 \mathrm{~mm}$ diameter) were then inserted into sand wells dug into the soil, and each electrode pair connected to a 110 Ampere-hour, 12 Volt battery. Electrode separation (anode to cathode) was $1.5 \mathrm{~m}$. Batteries were recharged every 4 days, and the soil re-saturated in the anodic compartment as required, typically every 10 - 14 days to maintain soil moisture / hydration. The treatment cell was fitted with a loosefitting fibre-glass lid to prevent rainwater ingress, while permitting escape of gases generated at the electrodes. Soil $\mathrm{pH}$ was monitored throughout the treatment period using a standard soil $\mathrm{pH}$ probe. Total treatment time was 60 days.

Following experiment termination test soils were destructively sampled for gamma spectroscopy, gross alpha beta counting and radiochemical analysis. A Russian corer was used to retrieve soil cores. 50 soil samples were retrieved from the treatment cell, in cross-cell transects, from soil depths of 20 $30 \mathrm{~cm}$ and $50-60 \mathrm{~cm}$. Each soil sample was approx. $60 \mathrm{ml}$ in volume. Once collected and labelled the material was consigned to AWE laboratories for analysis, using standard radiochemical, gross alpha and beta, and gamma spectrometric methods (as outlined above).

\section{Results}

\subsection{Laboratory proof of concept and optimisation trials.}

\subsubsection{Effectiveness of electrokinetic treatment in different soil types.}

While all soils tested showed an initially neutral $\mathrm{pH}$ (6 - 6.5), a clear $\mathrm{pH}$ gradient (of $c a$. $\mathrm{pH} 3 / 4-10$ ) rapidly developed during treatment, most strongly in the North Ponds (type 1) soil (Table 1). Element remobilisation / redistribution was most apparent in this soil (figure 3a), with ITRAX data indicating: (a) supply of Fe to the anodic compartment of the cell (via electrode dissolution), with subsequent precipitation of $\mathrm{Fe}$ (as Fe oxides / oxyhdroxides [14,15]) across the anodic zone on experimental completion / cessation of applied voltage [14]; (b) mobilisation of Mn in the anodic compartment, followed by migration towards the cathode and precipitation at the interface between the acid and alkaline zones (where a black precipitate was visually observed); and (c) mobilisation of $\mathrm{Ca}$ and $\mathrm{Sr}$ 
from the anodic compartment, with subsequent migration towards the cathode and precipitation (most likely as carbonates) on encountering alkaline conditions in the cathodic compartment. These trends were confirmed by (a) repeat scanning of differently orientated soil sections via ITRAX, and (b) WDXRF analysis (data not shown) on destructively-sampled material. Given the extreme pHs observed in the system, the relative complexity of the soil medium, and the complex redox-active chemistries of $\mathrm{Fe}$ and $\mathrm{Mn}$, it is extremely difficult to model elemental speciation in this system. However, based on the bulk elemental data and $\mathrm{pH}$ field it seems likely that $\mathrm{Fe}$ and $\mathrm{Mn}$ are mobilised predominantly in their reduced cationic states (i.e. $\mathrm{Fe}^{2+}$ and $\left.\mathrm{Mn}^{2+}\right)$ and $\mathrm{Ca}$ and $\mathrm{Sr}$ as their divalent cations $\left(\mathrm{Ca}^{2+}\right.$ and $\mathrm{Sr}^{2+}$ ). The elemental behaviour is consistent with previous observations in other soil media using the FIRS system ([14], figure 1). Similar element mobilisation was observed in the type 2 and type 3 soils (figure $3 b$ and $3 c$ ), although the trends are less distinct, particularly in the type 3 soils, which may be a result of higher carbonate content / buffering in this material (Table 1). Of the trace elements examined, zinc showed clear mobilisation in the applied electric field. Zinc was present in the North Ponds material at concentrations well above local geochemical background (concentrations of 570 ppm were observed in the untreated soil, $c a .4 .7$ times the expected local background of $120 \mathrm{ppm}$ [22]), indicating enrichment due to anthropogenic activities. ITRAX (and WDXRF) data indicate that during treatment $\mathrm{Zn}$ was mobilised from the acid zone (most likely in its $\mathrm{Zn}^{2+}$ form), migrated towards the cathode and precipitated on encountering alkaline conditions, either as a carbonate or hydroxide phase, or co-precipitated with $\mathrm{Fe} / \mathrm{Mn}$ oxides and oxyhydroxides (figure 3). $\mathrm{Cl}$ and $\mathrm{Br}$ (data not shown) generally migrated towards the anode, most likely as $\mathrm{Cl}^{-}$and $\mathrm{Br}^{-}$, consistent with previous observations (e.g. [14]).

Soil samples were screened using gross alpha and beta analysis, to test for general remobilisation of actinides (including $\mathrm{Pu}$ ) in the three soil types. There was little evidence for any significant actinide movement in the type 2 soils, but some evidence for actinide mobilisation and concentration around the boundary between the anodic and cathodic compartments in the type 1 and 3 soils (figure 4), following the major element (particularly $\mathrm{Mn}$ and $\mathrm{Ca}$ ) distribution. The extent and characteristics of this mobilisation was further examined in the second phase of the laboratory trials (see 4.1.2 below). In general, the relative degree of element mobilisation in the three soil types followed the order type 1 (North Ponds) > type 2 (Waste Management Group) $\geq$ type 3 soils (although the latter soils showed greater evidence for actinide / gross alpha and beta mobilisation). While all treatment cells developed a strong $\mathrm{pH}$ gradient, the extent of elemental remobilisation is highly dependant on the buffering capacity of the soil (high carbonate buffering inhibits the electrokinetic treatment process (and consequent mobilisation of $\mathrm{Pu}$ )), and soil mineralogy / composition. 


\subsubsection{Effect of soil porewater ionic strength / application of soil pre-conditioning agents.}

The initial experiments described above showed preliminary evidence for actinide mobilisation during electrokinetic treatment, and so the type 3 soils (the soil media to be targeted in the field trial) were further tested for $\mathrm{Pu}$ (as opposed to general actinide) mobilisation, using solutions of varying ionic strength, and with addition of the common soil pre-conditioning agent citric acid (to reduce the carbonate content of the soil and to enhance the mobilisation of $\mathrm{Pu}$ ). All cells showed development of a clear $\mathrm{pH}$ gradient (Table 1$)$, although clearly acidic conditions $(\mathrm{pH}<4)$ only developed in the cells conditioned with seawater and citric acid. Notably, despite the initial addition of an acid agent, strongly alkaline conditions (of up to $\mathrm{pH} 13$ ) still developed around the cathode in the citric acidconditioned cell.

No significant mobilisation of $\mathrm{Pu}$ was observed in the cell pre-conditioned with seawater, despite the higher ionic strength porewaters which increase conductivity and current flow, and the relatively intense $\mathrm{pH}$ gradient ( $\mathrm{pH} 3-13$, Table 1). Slight mobilisation of Pu was observed in the cell with AWE site-derived groundwater (data not shown), with mobilisation apparently occurring in the (slightly acidic) anodic compartment, with migration towards the cathode, consistent with migration of $\mathrm{Pu}$ either in a (dominantly) cationic form or as a colloidal species. In contrast, clear mobilisation of $\mathrm{Pu}$ was observed in the cell pre-conditioned with $30 \%$ citric acid, with both porewater and solid phase $\mathrm{Pu}$ data (figure 5a) indicating mobilisation and migration of $\mathrm{Pu}$ towards the anode, consistent with the migration of $\mathrm{Pu}$ as a negatively charged (anionic) complex. Whilst the difficulty in accurately modelling element speciation (in the case here, $\mathrm{Pu}$, which can co-exist in four different oxidation states, III to VI, in the same solution) in such a complex system under extreme $\mathrm{pH}$ gradients has been noted above, $\mathrm{Pu}$ is present in the soil environment mostly as hydroxides and oxides of $\mathrm{Pu}(\mathrm{IV})$ which have low solubility [23]. Surface sorption is a dominant feature of plutonium behaviour in soil systems, with strong sorption of Pu to mineral (Fe and Mn oxides, clays) and organic surfaces [24,25]. The addition of organic acids such as citric acid, or other chelating agents, can significantly enhance the solubility of $\mathrm{Pu}$ (and indeed other metals [10]), with citric acid forming a strong complex with $\mathrm{Pu}(\mathrm{IV})$, facilitating its use in a number of trials as an extractant for Pu from contaminated soils [26]. Francis et al [27] note in studies of the biotransformation of $\mathrm{Pu}(\mathrm{IV})$ in the presence of excess citric acid the formation of the mononuclear biligand Pu-cit ${ }_{2}$ complex, while Cleveland [28] notes the formation of exceptionally strong $\mathrm{Pu}(\mathrm{IV})$-citrate complexes at $\mathrm{pH}>$ or $=5$ (e.g. $\left.\mathrm{Pu}\left(\mathrm{C}_{6} \mathrm{H}_{5} \mathrm{O}_{7}\right)_{4}{ }^{8-}\right)$. In the cell tested here, $\mathrm{Pu}$ showed clearly enhanced porewater concentrations, and solid phase activities almost three times higher than in the pre-treatment soil material, in the anode zone (figure 5a). Uranium, present in these soils mostly at geological background concentrations / specific activities, showed similar migration towards the anodic compartment, consistent with formation of negatively charged U-citrate complexes (authors' unpublished data). ITRAX geochemical data (confirmed by WD-XRF on destructively sampled material) for the cell (figure $5 b$ ) indicate a position for the 
acid:alkaline $\mathrm{pH}$ boundary at the extreme right of the cell (adjacent to the cathode - shown by clear maxima in $\mathrm{Mn}, \mathrm{Ca}$ and $\mathrm{Sr}$ at this point), with the bulk of the cell experiencing acidic conditions ( $c a$. $\mathrm{pH} 3)$.

\subsection{Field (pilot) trial results.}

As in the laboratory trials, a significant $\mathrm{pH}$ gradient developed in the treated material during the larger volume field (pilot) trials (figure 6), with acidic conditions generated around the anodes, and alkaline conditions around the cathodes. Following soil treatment and destructive sampling of the cell, gross alpha-beta analysis was applied (to allow comparison with UK regulatory / disposal thresholds) supported by solid phase Pu determinations. While little remobilisation of $\mathrm{Pu}$ was observed around the margins of the field treatment cell (which is likely to be a result of "edge effects" i.e. dissipation of the electric field around the cell margins, see also [29]), clear reduction in gross alpha beta activity (of which $\mathrm{Pu}$ forms the significant fraction in these soils), and mobilisation of $\mathrm{Pu}$ was observed in the cathodic compartment in the central cell area (figure 7), with migration to, and enrichment of, gross alpha beta activity and $\mathrm{Pu}$ in the anodic compartment. This is consistent with the laboratory trials using citric acid (although here the concentrations of citrate are far more dilute, at $0.04 \mathrm{M}$ ), with $\mathrm{Pu}$, and possibly other alpha and beta emitters, being dissolved from the soil media and forming a negatively-charged and relatively stable (presumably citrate) complex, which migrated toward the anodic cell compartment.

Citrate concentrations were not measured during the trial due to logistical difficulties, but the concentration of citrate and other chelating agents will be controlled by a combination of breakdown / biological utilisation of citric acid in the cell, mechanical addition during cell rewatering, and production of citric (and other) acid(s) by bacterial action. Despite uncertainties over the exact chemical speciation and dissolution / precipitation dynamics of the Pu present, it is clear that a fraction of the soil has been remediated to a level that allows its reclassification as non-radioactive (i.e. below so-called "free release" thresholds, at $1.7 \mathrm{~Bq} / \mathrm{g}$ ). Specifically, the background activity (for alpha and beta emitting radionuclides) of soils on the AWE PLC Aldermaston site is $1.3 \mathrm{~Bq} / \mathrm{g}$. Material with total alpha beta radioactivity $<0.4 \mathrm{~Bq} / \mathrm{g}$ above background (i.e. activity less than $1.7 \mathrm{~Bq} / \mathrm{g}$ ) does not require any specialist arrangements for disposal, and can be disposed to conventional landfill. Therefore $1.7 \mathrm{~Bq} / \mathrm{g}$ represents the target level for the remediation process. The volume of soil remediated to below the $1.7 \mathrm{~Bq} / \mathrm{g}$ threshold here is approximately $0.4 \mathrm{~m}^{3}$, or $1 / 6$ of the starting material volume. 


\section{Discussion}

Results from the field trial indicate that despite the use of a low-voltage, relatively simple electrokinetic application, significant remobilisation and relocation of $\mathrm{Pu}$ occurred. While the $\mathrm{Pu}$ did not separate as a clear, concentrated band, a portion of the soil was remediated to below activity thresholds which would allow its disposal to landfill as non-radioactive material following mechanical excavation from the cell. Even at low concentrations of citric acid $(0.04 \mathrm{M})$, the $\mathrm{K}_{\mathrm{d}}$ for $\mathrm{Pu}$ is significantly lowered and $\mathrm{Pu}$ dissolution occurs, even in a highly buffered system where $\mathrm{Pu}$ is expected to show very high particle reactivity $\left(\mathrm{K}_{\mathrm{d}}=10^{6}\right.$, [13]). The treatment system was operated on site, but ex-situ, reflecting (a) the form of the waste material requiring treatment (which was held onsite in waste containment units), and (b) potential problems (in terms of releasing contamination to groundwater) of mobilising $\mathrm{Pu}$ in the subsurface, if the technique were applied in-situ. While the FIRS technique has potential applicability for in-situ use (particularly in terms of generating subsurface containment barriers, stabilising contaminants and reductive trapping of elements such as Cr, e.g. [14, 17, 18]) the potential for Pu release in the subsurface, and the complex behaviour exhibited by $\mathrm{Pu}$ in the strong $\mathrm{pH}$ gradients generated by the technique, mean that on-site ex-situ use is currently more technically and operationally feasible. Plutonium separation / removal could be enhanced via use of a leachate control and water recirculation system, as used in a parallel field trial undertaken on $\mathrm{Cr}$ contaminated soil wastes [17], or via optimisation of the electrode configuration. The voltage applied in the trial was extremely low: approximately $0.08 \mathrm{~V} / \mathrm{cm}$, compared to the $1 \mathrm{~V} / \mathrm{cm}$ or greater typically used in conventional electrokinetic trials (e.g. [10]). Power consumption was approximately $55 \mathrm{~W} / \mathrm{hr}$, or $33 \mathrm{kWh} / \mathrm{m}^{3}$ over the 60 day duration of the trial. This compares favourably to published field / pilotscale data on other electrokinetic remediation techniques, where power consumption frequently exceeds $200-500 \mathrm{kWh} / \mathrm{m}^{3}$ (at similar electrode separations [30-32]). The lack of on-site electrical supply necessitated the use of a recyclable battery array to provide power, which was successful, and indicated the potential to use the technique at low-cost (both in terms of power supply and materials), at relatively remote site locations. Of note is that the technology forms a relatively passive treatment process for contaminants once set-up, which can continue at relative low cost and impact to site operations until remediation targets have been achieved. The overall cost of materials, set-up, implementation and decommissioning for the field trial (excluding the original cost of the containment unit and staff costs) was in the order of $£ 4000$, or approximately $£ 1700 / \mathrm{m}^{3}$ ( $£ 1000$ per tonne) of material treated. This compares to an approximate direct disposal cost of $c a$. $£ 5000$ per $\mathrm{m}^{3}$ (estimate based on current disposal costs at the low level waste repository facility at Cumbria, U.K, and cost of packaging, verification, transport etc).

Although the efficiency of remediation at any site will be highly dependant on local soil mineralogy and buffering capacity, the experiments detailed here illustrate the potential effectiveness of lowenergy electrokinetic remediation as a waste minimisation method for $\mathrm{Pu}$ - (and other radioactively) 
contaminated soils. More generally, the enhanced mobility of Pu (and, based on the laboratory trials, $\mathrm{Sr}$ and $\mathrm{Cl}$ ) observed under these low-intensity electrical fields has implications for the near-surface storage and landfilling of nuclear wastes / contaminated soils. While $\mathrm{Sr}$ and $\mathrm{Cl}$ isotopes are generally known to be relatively highly mobile components of nuclear waste materials, $\mathrm{Pu}$ (depending on its oxidation state) is considered much less so (e.g. [13]). The data presented here indicate that enhanced redissolution of $\mathrm{Pu}$ can occur in electric fields similar in magnitude to those which are generated via natural redox reactions across a range of soil and sedimentary rock types (e.g. [33]), which, particularly in combination with microbial transformations involving production and degradation of organic acids, may provide a mechanism for accelerated Pu release from waste containment sites.

\section{Acknowledgements.}

The authors are grateful to AWE PLC and the Knowledge Transfer Partnerships (KTP) programme for project funding. We thank two anonymous reviewers for helpful and insightful comments on an earlier version of this paper.

\section{Tables.}

Table 1: General physical and chemical characteristics of test soils used, and $\mathrm{pH}$ gradients observed during electrokinetic treatment (in laboratory trials). Detailed soil characterisation was not possible due to the radioactive nature of the samples, which limited sample handling, but descriptions of the soils (based on visual logging) and basic chemical compositional data are given. Elements are reported as oxides following XRF geochemical convention. ${ }^{1}$ Determined from WDXRF data. ${ }^{2} \% \mathrm{CaO}$ includes Ca present in $\mathrm{CaCO}_{3}$, clays and other soil components. Soil $3 \mathrm{CaCO}_{3}$ content was determined as $6.3 \%$, using standard titration techniques.

\section{Figures.}

Figure 1: Schematic diagram of the FIRS (Ferric Iron Remediation and Stabilisation) electrokinetic technique (a), and typical element distribution in treated soil following application of FIRS (from [14]) (b). In (b), the precipitated $\mathrm{Fe}$ band is located $5 \mathrm{~cm}$ from the anode. $\mathrm{Fe}, \mathrm{Mn}$, and $\mathrm{Ca}$ are reported as oxides, according to XRF geochemical convention. The dashed horizontal line on each graph shows the mean concentration in the untreated sediment. See [14] for full experimental details.

Figure 2: Lined treatment cell used for field-scale trial (a). (b) shows schematic of electrode placement.

Figure 3: Fe, Mn, Zn, Ca and Sr distribution in (a) Soil type 1, (b) Soil type 2 and (c) Soil type 3. Data are from ITRAX scanning: $\mathrm{x}$-axis represents scan distance (anode at extreme left of axis, cathode at extreme right), $\mathrm{y}$-axis shows $\mathrm{X}$-ray response. 
Figure 4: Gross alpha and Gross beta distribution in (a) Soil type 1, (b) Soil type 2 and (c) Soil type 3. $\mathrm{X}$-axis label "Fe/Mn band" in (a) shows position of black precipitate generated in cell during electrokinetic soil treatment (see section 4.1.1 for discussion).

Figure 5: (a) Pu distribution in citric acid-amended type 3 soil material, after 32 days treatment. Upper graph shows $\mathrm{Pu}$ distribution in porewaters, lower graph shows $\mathrm{Pu}$ distribution in soil (solid) phase. Horizontal line on lower graph shows pre-treatment Pu activity in the soil. (b) Fe, Mn, Ca and Sr distribution in citric acid-amended type 3 soil material, following treatment. Data are from ITRAX scanning: $x$-axis represents scan distance (anode at extreme left of axis, cathode at extreme right), yaxis shows $\mathrm{X}$-ray response.

Figure 6: $\mathrm{pH}$ in field cell on commencement of electrokinetic field trial (a), and after 60 days treatment (b).

Figure 7: Gross alpha and Gross beta (a) and Pu (b) distribution in treated soil at completion of field trial. In (a), "top" shows gross alpha-beta activity near to the surface of the field cell (i.e. at $20-30 \mathrm{~cm}$ depth), "bottom" shows gross alpha-beta activity near to the base of field cell (i.e. at $50-60 \mathrm{~cm}$ depth). Horizontal line on (a) shows the threshold for free release disposal (see text for discussion).

\section{References}

[1] RWMAC (Radioactive Waste Management Advisory Committee), Twenty First Annual Report of the Radioactive Waste Management Advisory Committee. Defra Publications, London, 2001.

[2] J.L. Schnoor, Phytoremediation, GWRTAC Technology Evaluation Report TE-98-01, 1997.

[3] H. Shahandeh, L.R. Hossner, Enhancement of uranium phytoaccumulation from contaminated soils, Soil Sci., 167 (2002) 269-280.

[4] A.S. Knox, J.C. Seaman, M.J. Mench, J. Vangronsveld, Remediation of metal- and radionuclidecontaminated soils by in-situ stabilisation techniques, in: Iskandar I.K. (Ed.) Environmental Restoration of Metals-Contaminated soils. Lewis Publishers, Boca Raton, Florida, 2000, pp. 21-60.

[5] C.W. Francis, M.E. Timpson, J.H. Wilson, Bench- and pilot-scale studies relating to the removal of uranium from uranium-contaminated soils using carbonate and citrate lixiviants, Jnl. Haz. Mat., 66 (1999) 67-87.

[6] C. Kantar, B.D. Honeyman, Citric acid enhanced remediation of soils contaminated with uranium by soil washing, J. Environ. Eng. 132 (2006) 247-255. 
[7] W.W. Kovalick, In situ remediation technology: electro-kinetics, U.S. Environmental Protection Agency, Office of Solid Waste and Emergency Response Technology Innovation Office, Washington. EPA542-K-94$007,1995$.

[8] J. Virkutyte, M. Sillanpaa, P. Latostenmaa, Electrokinetic soil remediation - critical overview, Sci. Tot. Env. 289 (2002) 97-121.

[9] V.A. Korolev, Electrokinetic removal of radionuclides, in: K.R. Reddy, C.Cameselle (Ed.) Electrochemical remediation technologies for polluted soils, sediments and groundwater, Wiley, New Jersey, 2009, pp 127 - 140

[10] L.M. Ottosen, H.K. Hansen, P.E. Jensen, Electrokinetic removal of heavy metals, in: K.R. Reddy, C. Cameselle (Eds.) Electrochemical remediation technologies for polluted soils, sediments and groundwater, Wiley, New Jersey, 2009, pp 97 - 126.

[11] C.J. Athmer, S.V. Ho, Field studies: Organic-contaminated soil remediation with Lasagna technology, in: K.R. Reddy, C.Cameselle (Eds.), Electrochemical remediation technologies for polluted soils, sediments and groundwater, Wiley, New Jersey, 2009, pp. 625 - 646.

[12] AWE plc. Environmental Stewardship, Atomic Weapons Establishment public information leaflet, Aldermaston, Reading, Berkshire, U.K., summer 2004.

[13] D. McCubbin, K.S. Leonard, R.C. Greenwood, B.R. Taylor, Solid-solution partitioning of plutonium in surface waters at the Atomic Weapons Establishment Aldermaston (UK), Sci. Tot. Env., 332 (2004) 203-216.

[14] A.B. Cundy, L.Hopkinson, Electrokinetic iron pan generation in unconsolidated sediments: implications for contaminated land remediation and soil engineering, Appl. Geochem., 20 (2005) 841-848.

[15] D.W.S. Faulkner, L. Hopkinson, A.B. Cundy, Electrokinetic generation of reactive iron-rich barriers in wet sediments: implications for contaminated land management, Min. Mag., 69 (2005) 749 - 757.

[16] R.F. Probstein, R.E. Hicks, Removal of Contaminants from Soils by Electric Fields, Science, 260 (1993) 498-503.

[17] L. Hopkinson, A.B. Cundy, R. Pollock, Electrokinetic ferric iron remediation and stabilisation (FIRS) of hexavalent chromium-contaminated soils: an ex-situ field-scale demonstration, CL:AIRE bulletin RB9,

CL:AIRE, London, UK. March 2009. 
[18] L. Hopkinson, A.B. Cundy, D. Faulkner, A. Hansen, R. Pollock, Electrokinetic stabilization of Cr(VI)contaminated soils, in: K.R. Reddy, C. Cameselle (Eds.) Electrochemical remediation technologies for polluted soils, sediments and groundwater, Wiley, New Jersey, 2009, pp 179-194.

[19] I.W. Croudace, A. Rindby, R.G. Rothwell, ITRAX: Description and evaluation of a new multi-function Xray core scanner, in: R.G. Rothwell (Ed.), New Techniques in Sediment Core Analysis, Geological Society, London, Special Publication, 267, 2006, pp. 51-63.

[20] P.E. Warwick, I.W. Croudace, A.A. Dale, An optimised and robust method for the determination of uranium and plutonium in aqueous samples, Appl. Radiat. Isot., 50 (1999) 579-583.

[21] I.W. Croudace, J. Gilligan, Versatile and accurate trace-element determinations in iron-rich and other geological samples using X-Ray-Fluorescence analysis, X-ray Spectrom., 19 (1990) 117-123.

[22] I.W. Croudace, A.B.Cundy, Heavy-metal and hydrocarbon pollution in recent sediments from Southampton Water, Southern England - a geochemical and isotopic study, Environ.Sci.Technol. 29 (1995) 1288-1296.

[23] A.J. Francis, Microbial transformations of plutonium and implications for its mobility, in: A. Kudo (Ed.), Plutonium in the environment, Elsevier, New York, 2001, pp. 201-219.

[24] G.R. Choppin, A. Morgenstern, Distribution and movement of environmental plutonium, in: A. Kudo (Ed.), Plutonium in the environment, Elsevier, New York, 2001, pp. 91-105.

[25] M.C. Duff, Speciation and transformations of sorbed Pu on geologic materials: wet chemical and spectroscopic observations, in: A. Kudo (Ed.), Plutonium in the environment, Elsevier, New York, 2001, pp. 139-157.

[26] A.J. Francis, C.J. Dodge, T.J. Ohnuki, Microbial transformations of plutonium, J. Nucl. Radiochem. Sci., 8 (2007) 121-126.

[27] A.J. Francis, C.J. Dodge, J.B. Gillow, Biotransformation of plutonium complexed with citric acid, Radiochim. Acta, 94 (2006) 731-737.

[28] J.M. Cleveland, The chemistry of plutonium, Gordon and Beach, New York, 1970.

[29] S. Glendinning, J. Lamont-Black, C.J.F.P. Jones, Treatment of sewage sludge using electrokinetic geosynthetics, Jnl. Haz. Mat., 139 (2007) 491-499.

[30] J. Van Deuren, T. Lloyd, S. Chhetry, R. Liou, J. Peck, Remediation Technologies Screening Matrix and Reference Guide, $4^{\text {th }}$ Edition, Federal Remediation Technologies Roundtable, www.frtr.gov, January 2002. 
[31] K.I. Popov, V.G. Yachmenev, A. Barinov, Enhancement of the electrokinetic remediation of soil contaminated with U(VI) by chelating agents, in: B. Nowack, J.M. VanBriesen (Eds.), Biogeochemistry of chelating agents, ACS Symposium Series Vol. 910, American Chemical Society, Washington D.C., 2005, pp $398-420$.

[32] D.M. Zhou, L. Cang, A.N. Alshawabkeh, Y.J. Wang, X.Z. Hao, Pilot-scale electrokinetic treatment of a Cu contaminated red soil, Chemosphere, 63 (2006) 964-971.

[33] K-H Jacob, S. Dietrich, H-J Krug, Self organised mineral fabrics, in: J.H. Kruhl (Ed.), Fractals and dynamic systems in geoscience, Springer Verlag, Berlin, 1996: pp 259-268. 


\begin{tabular}{|c|c|c|c|c|c|c|c|c|c|}
\hline Soil & Description & $\begin{array}{c}\text { Soil pH } \\
\text { (before } \\
\text { treatment) }\end{array}$ & $\begin{array}{c}\text { Ignitable } \\
\text { content } \\
(\%)^{1}\end{array}$ & $\begin{array}{c}\mathrm{SiO}_{2} \\
(\mathrm{wt} . \%)\end{array}$ & $\begin{array}{c}\mathrm{Al}_{2} \mathrm{O}_{3} \\
(\mathbf{w t} \%)\end{array}$ & $\begin{array}{c}\mathrm{CaO} \\
(\mathrm{wt} . \%)\end{array}$ & Wetting agent & $\begin{array}{l}\text { Lowest } \\
\text { pH } \\
\text { recorded } \\
\text { (anode } \\
\text { zone) }\end{array}$ & $\begin{array}{l}\text { Highest } \\
\text { pH } \\
\text { recorded } \\
\text { (cathode } \\
\text { zone) }\end{array}$ \\
\hline $\begin{array}{l}\text { Soil type 1: North } \\
\text { Ponds area sediment }\end{array}$ & $\begin{array}{l}\text { Brown friable silt } \\
\text { and clay with } \\
\text { common organic } \\
\text { fragments and flint } \\
\text { pebbles }\end{array}$ & 6 & 15 & 61 & 6 & 2.5 & $\begin{array}{l}\text { AWE Aldermaston site } \\
\text { groundwater }\end{array}$ & 3 & 10 \\
\hline $\begin{array}{l}\text { Soil type } 2 \text { : Waste } \\
\text { management group } \\
\text { soils }\end{array}$ & $\begin{array}{l}\text { Clay-rich with } \\
\text { common flints. } \\
\text { Little organic } \\
\text { matter. }\end{array}$ & 6 & 10 & 70 & 9 & 3.8 & $\begin{array}{l}\text { AWE Aldermaston site } \\
\text { groundwater }\end{array}$ & 4 & 10 \\
\hline \multirow{3}{*}{$\begin{array}{l}\text { Soil type } 3 \text { : Excavated } \\
\text { soils from previous } \\
\text { clean-up operations (= } \\
\text { soil utilized for on-site } \\
\text { trial) }\end{array}$} & \multirow{3}{*}{$\begin{array}{l}\text { Clay-rich soil with } \\
\text { common flints. } \\
\text { Some organic } \\
\text { remains present. }\end{array}$} & \multirow[t]{3}{*}{6.5} & \multirow[t]{3}{*}{12} & \multirow[t]{3}{*}{62} & \multirow[t]{3}{*}{5} & \multirow[t]{3}{*}{11} & $\begin{array}{c}\text { AWE Aldermaston site } \\
\text { groundwater }\end{array}$ & 4 & 10 \\
\hline & & & & & & & Sterilised seawater & 3 & 13 \\
\hline & & & & & & & $30 \%$ citric acid solution & 3 & 13 \\
\hline
\end{tabular}

Table 1 
(a)

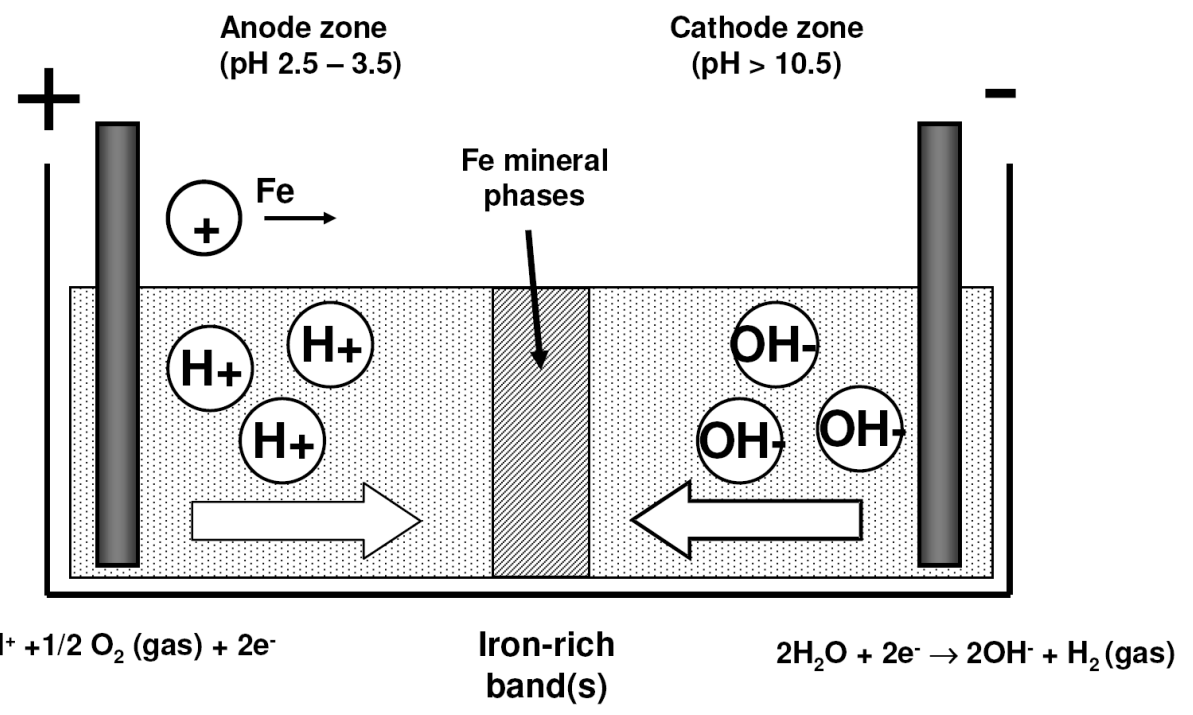

(b)

$\mathrm{Fe} 2 \mathrm{O3}$
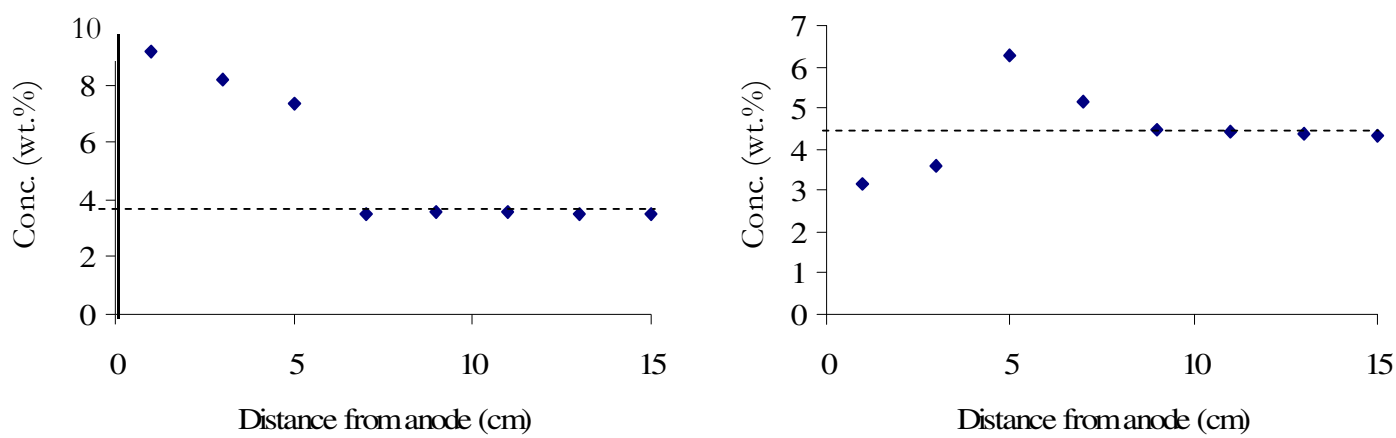

MnO

Sr
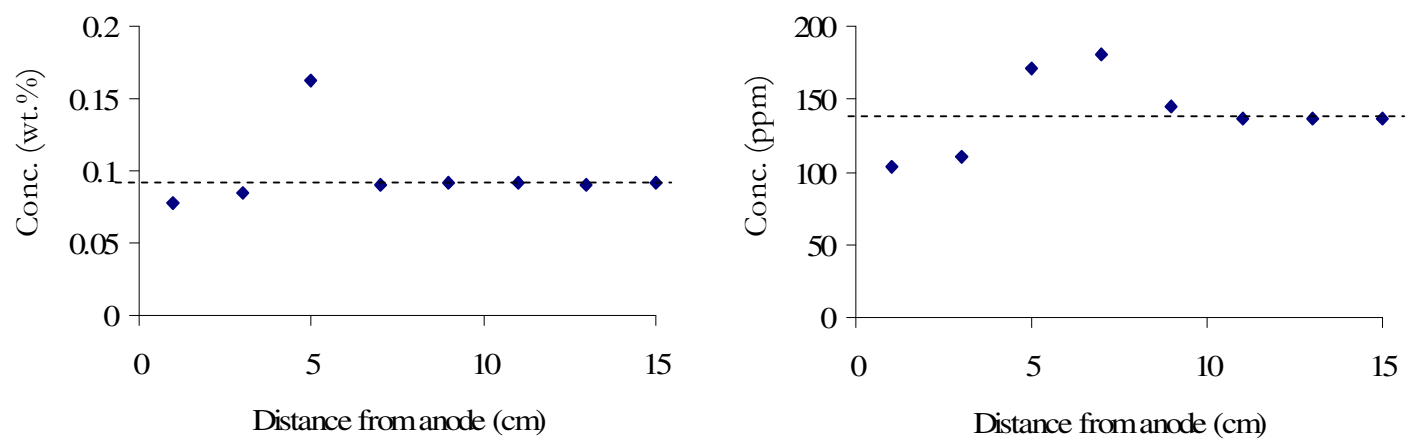

Figure 1 
(a)

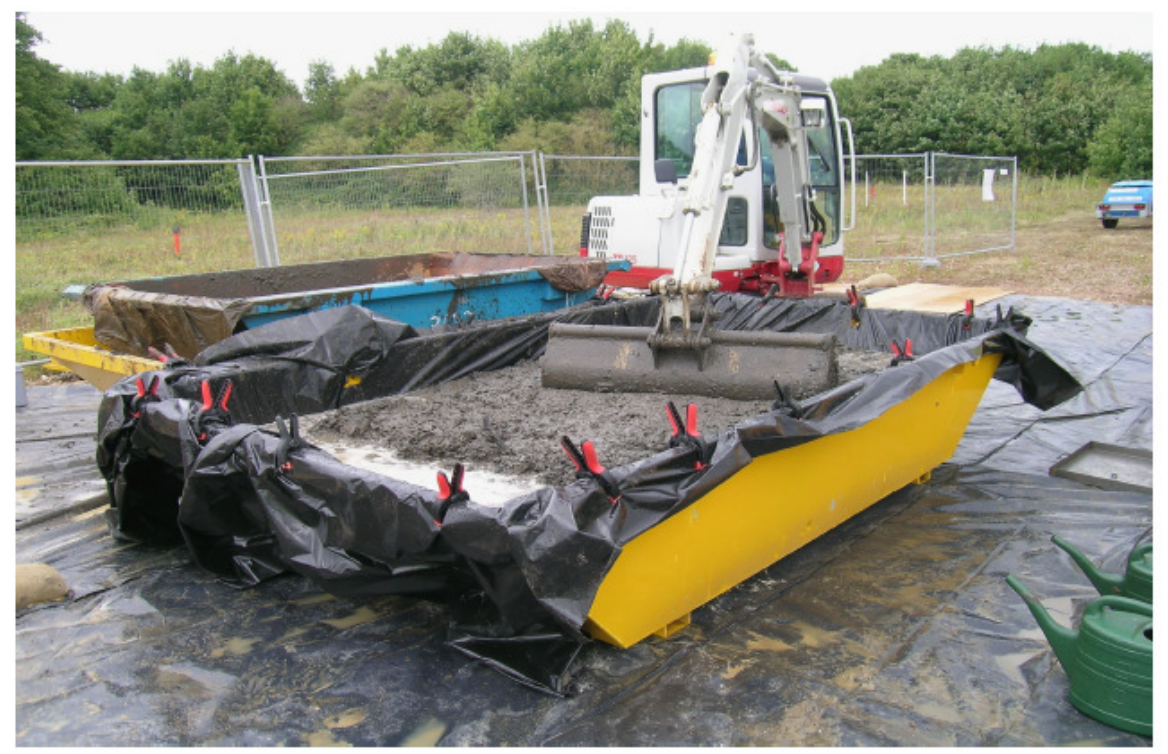

(b)

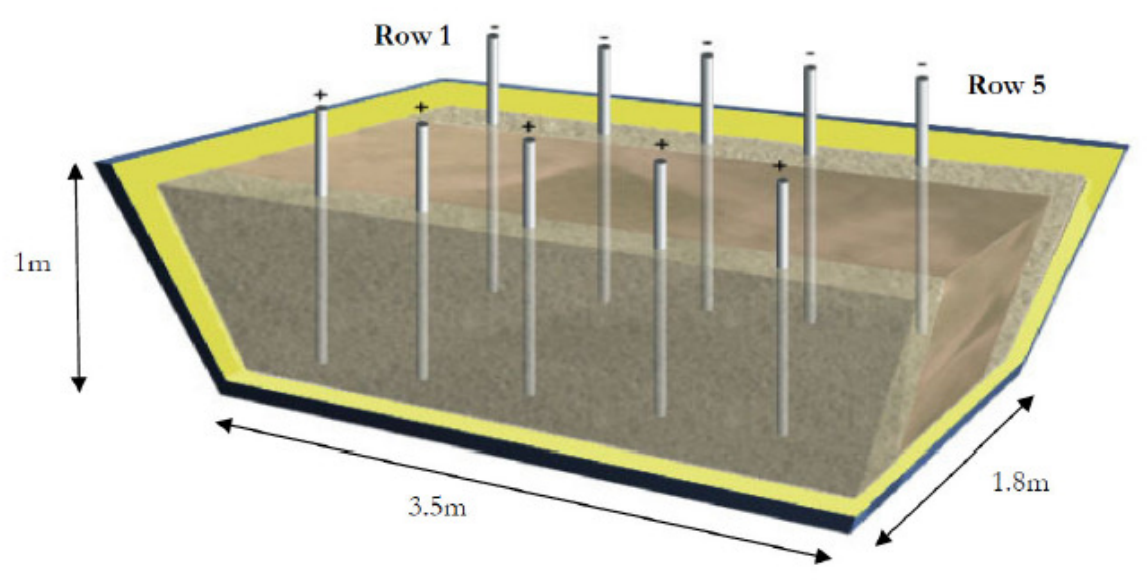

Figure 2 


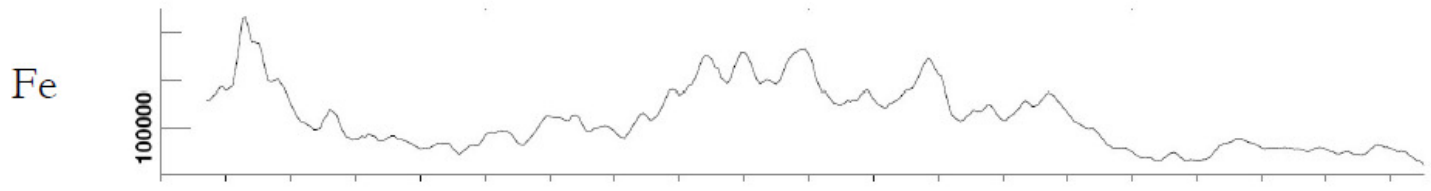

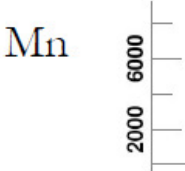

$\mathrm{Zn}$

$\mathrm{Ca} \quad \begin{gathered}\mathrm{o} \\ \mathrm{n} \\ \mathrm{n}\end{gathered}$

Sr

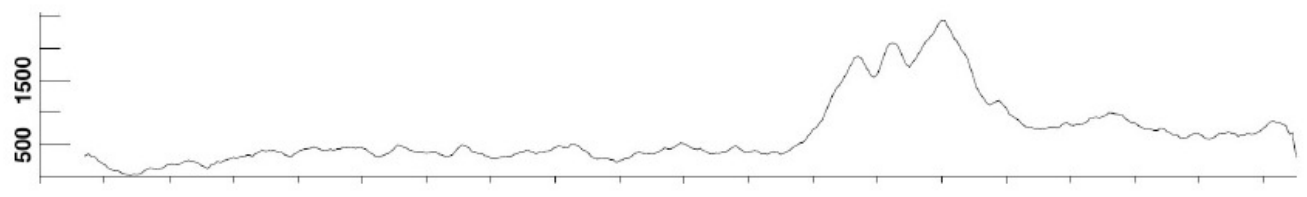

Figure 3 (a) 
$\mathrm{Fe}: \stackrel{-}{-}$

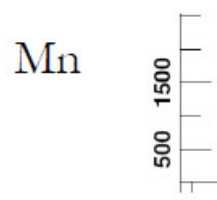

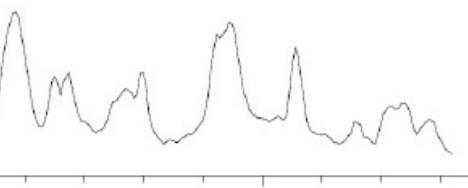

Zn $\begin{aligned} E \\ \text { E }\end{aligned}$

$\mathrm{Ca}$

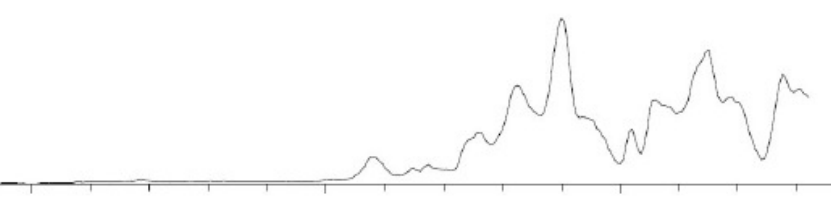

Sr

Figure 3 (b) 
$\mathrm{Fe} \quad \mathrm{o}_{+}^{+}$
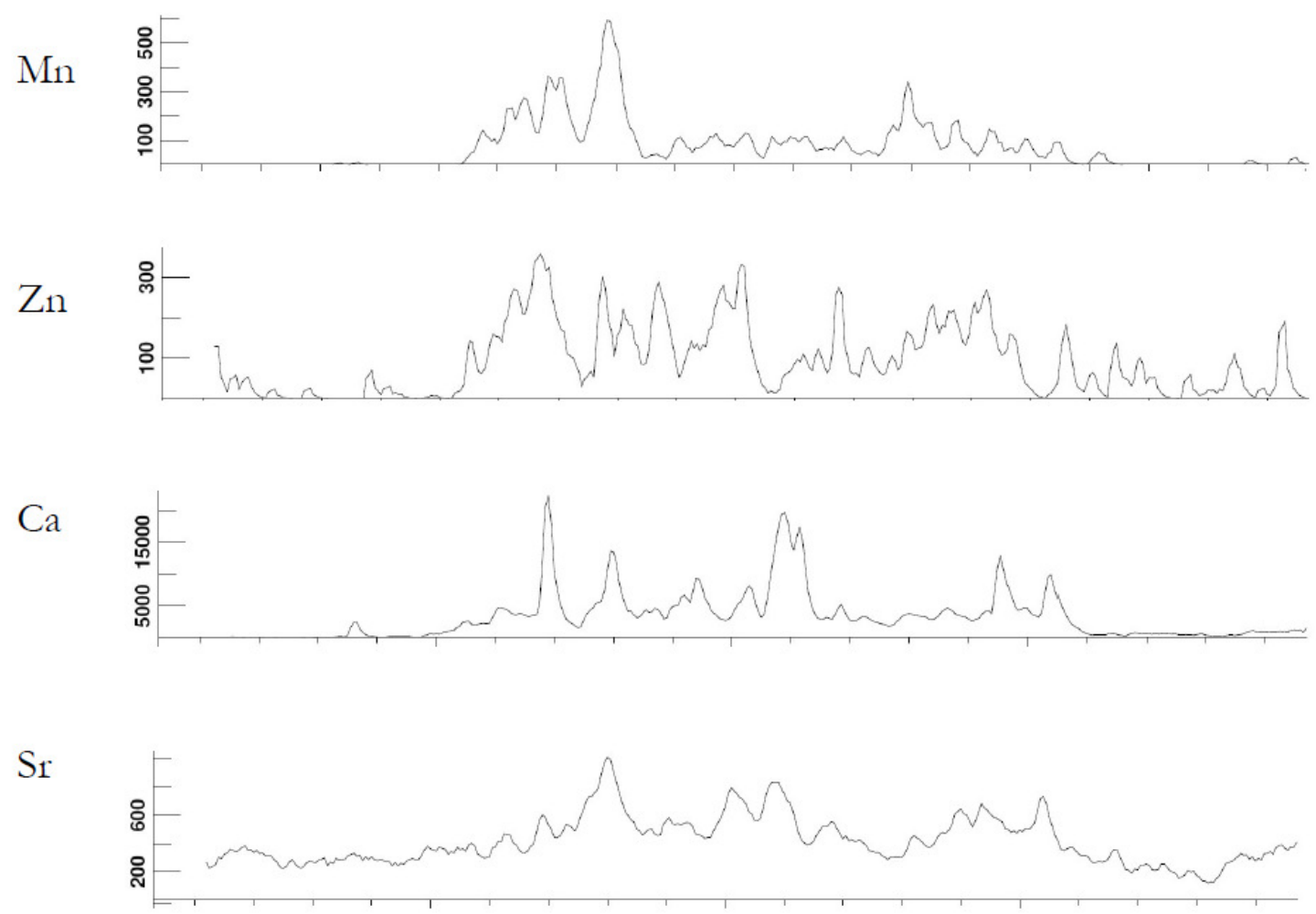

Figure 3 (c) 
Gross Alpha Beta Distribution - Soil Type 1

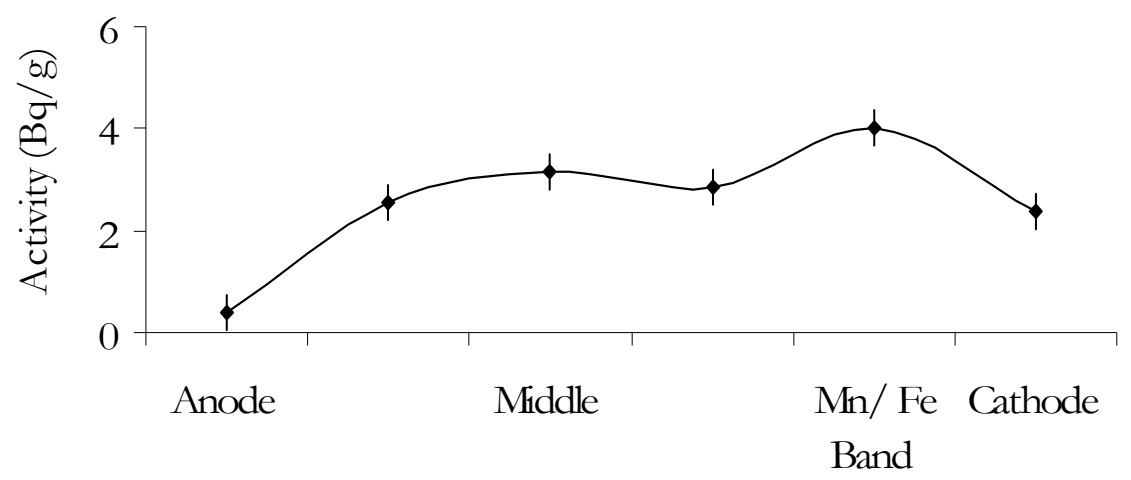

Gross Alpha Beta Distribution - Soil Type 2

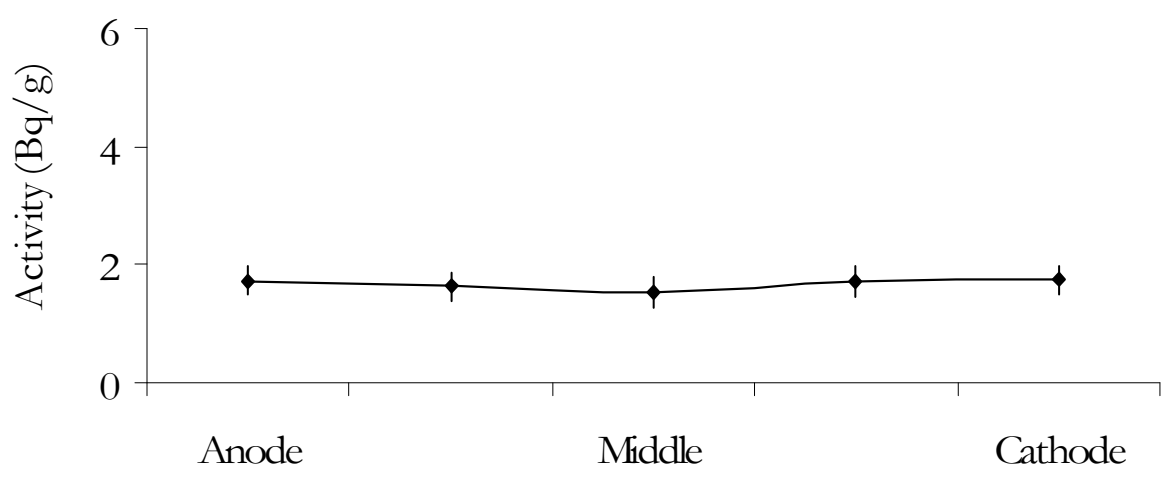

Gross Alpha Beta Distribution - Soil Type 3

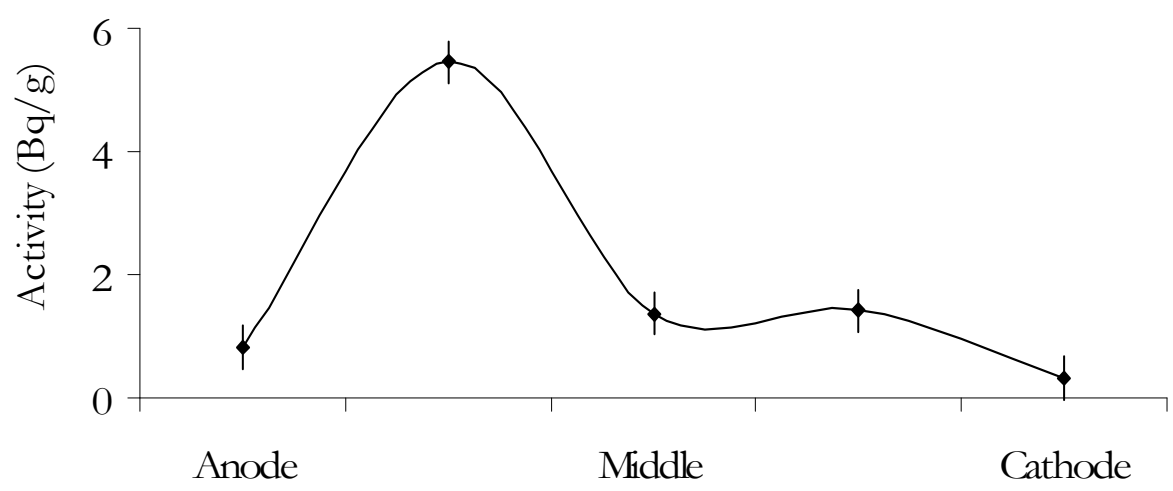

Figure 4 

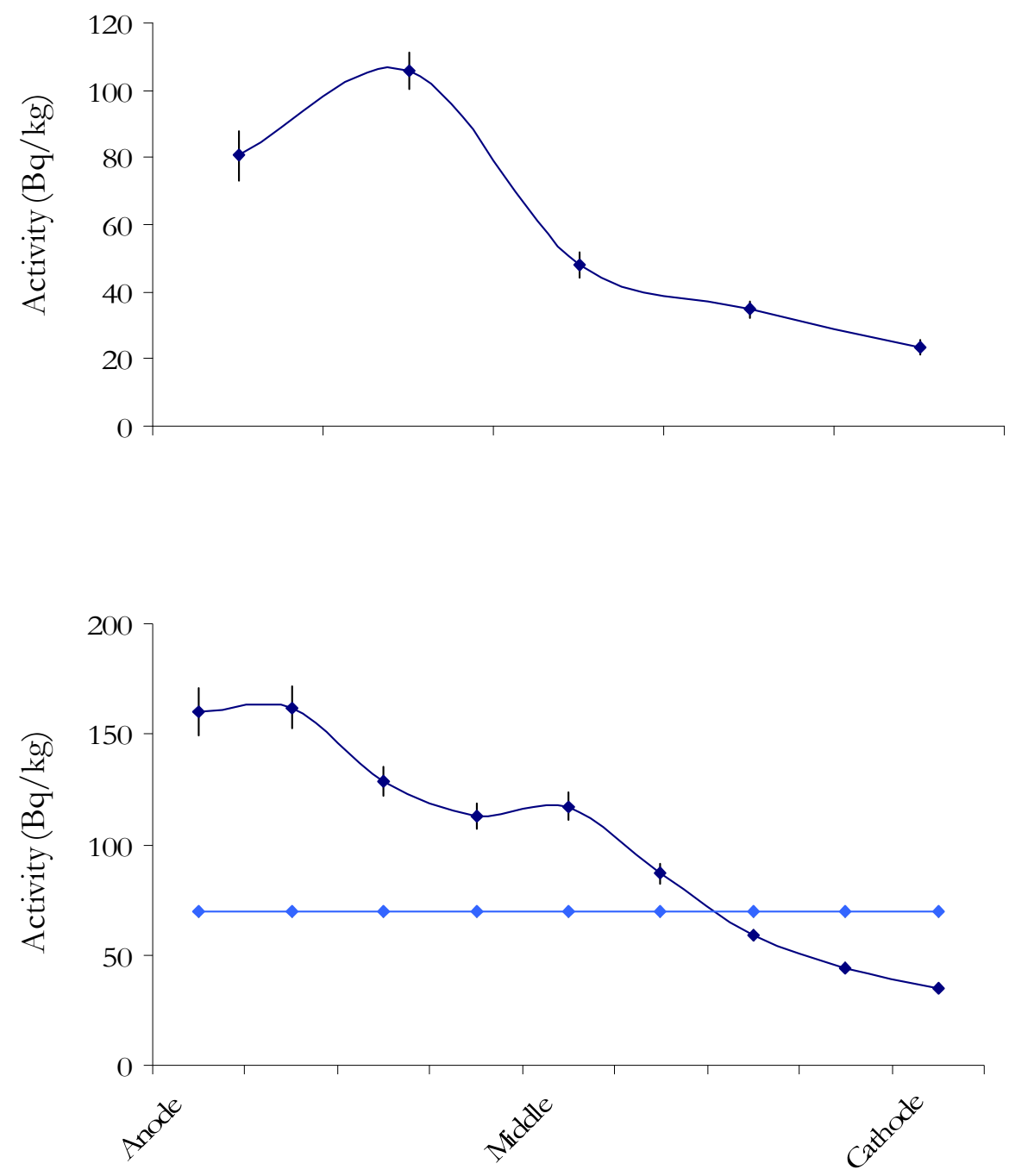

Figure 5 (a) 

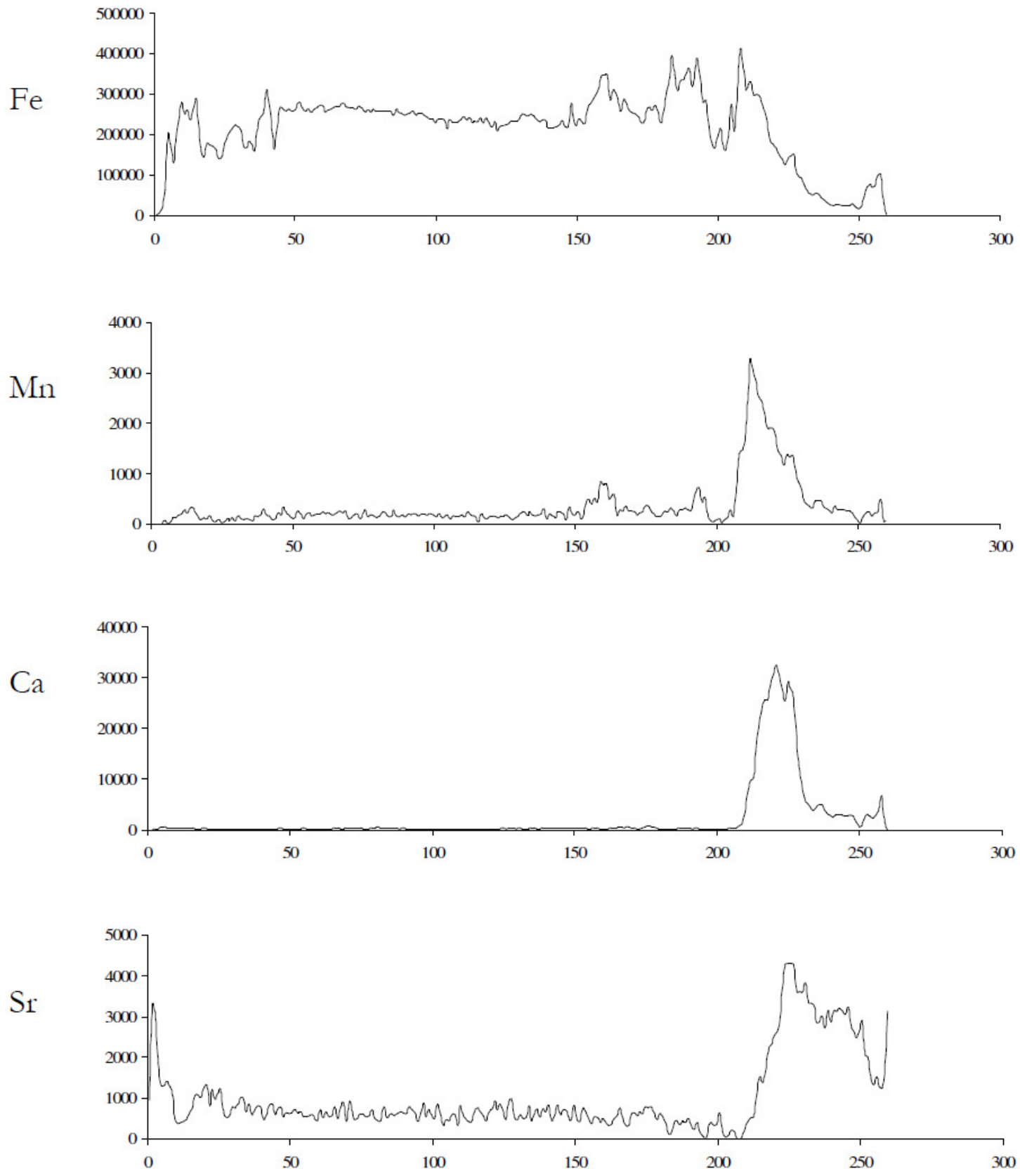

Figure 5 (b) 
pH Gradient: Day 1

(a)

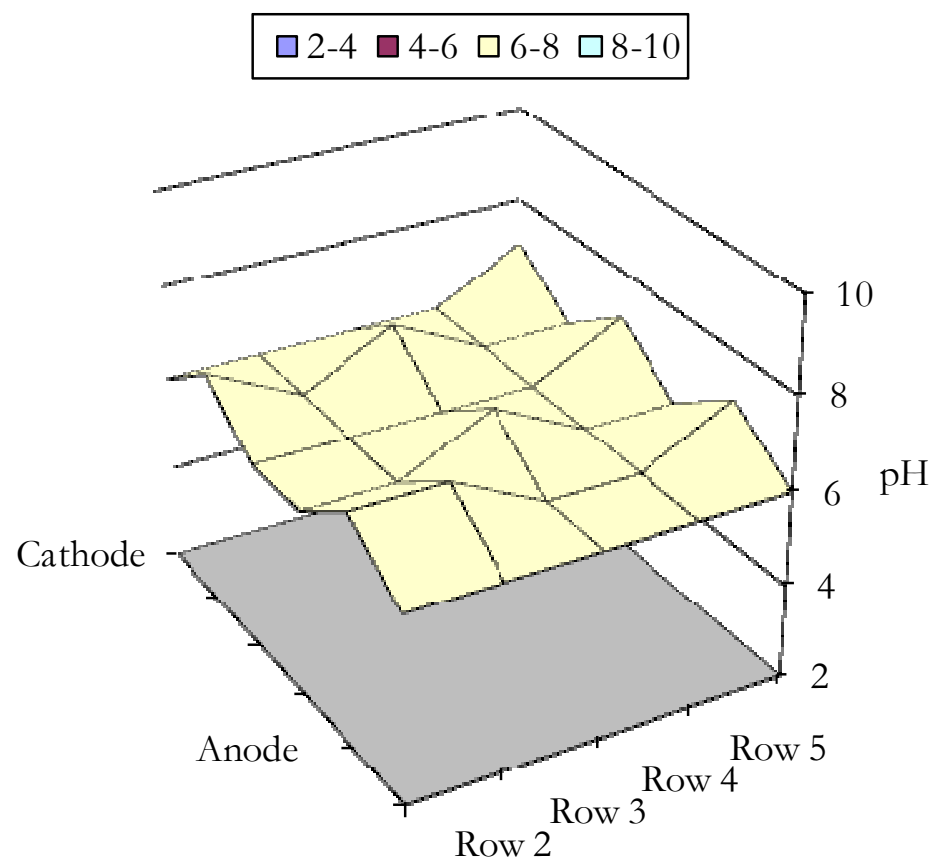

Row 1

Electrode Row

(b)

pH Gradient: Day 60

Figure 6

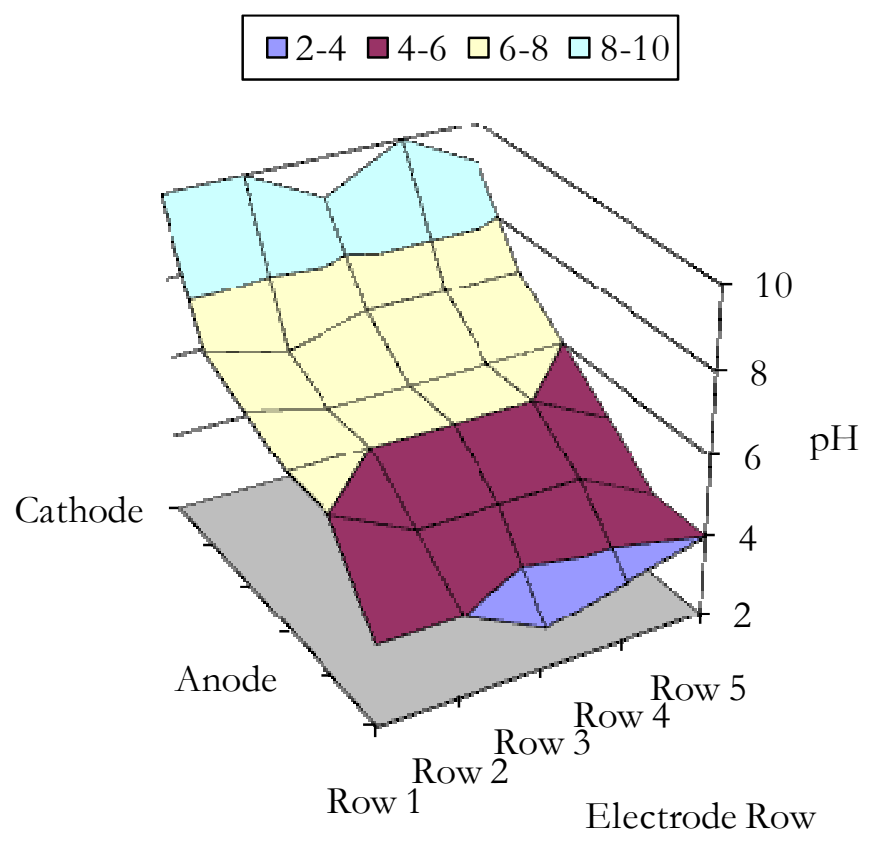


Gross Alpha Beta Distribution - Row3

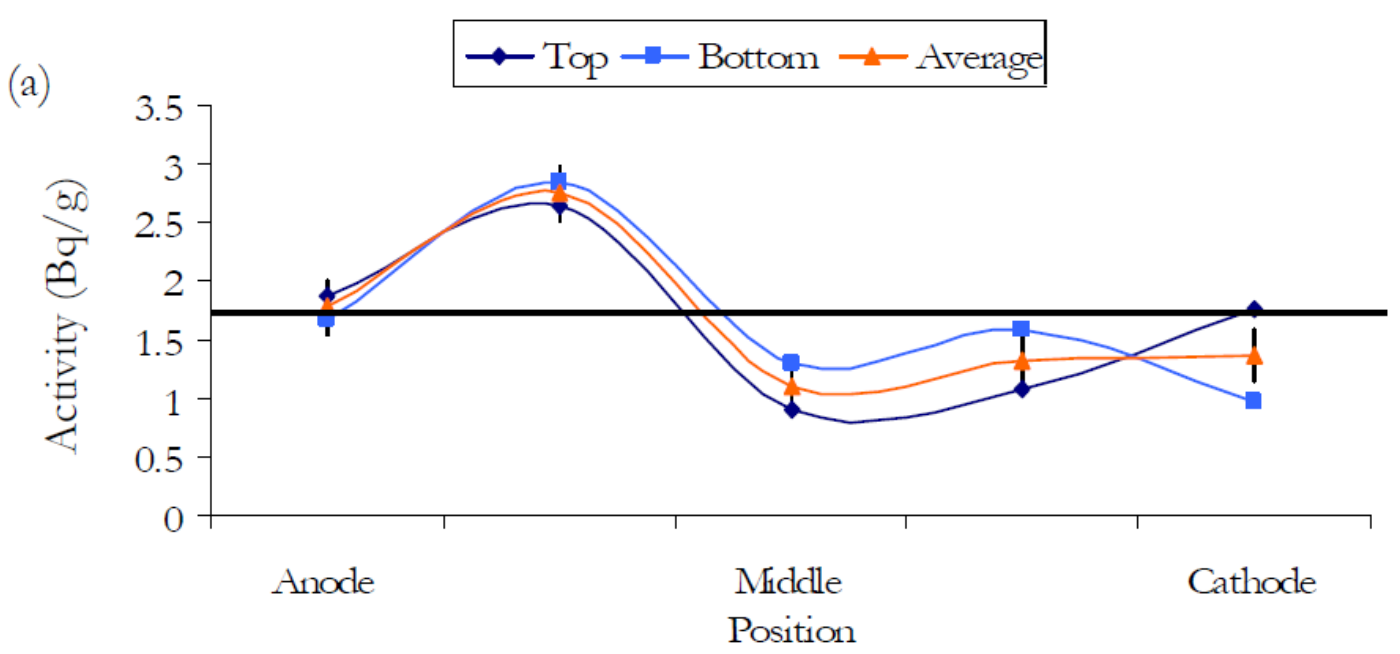

(b)

Pu distribution - Row 3

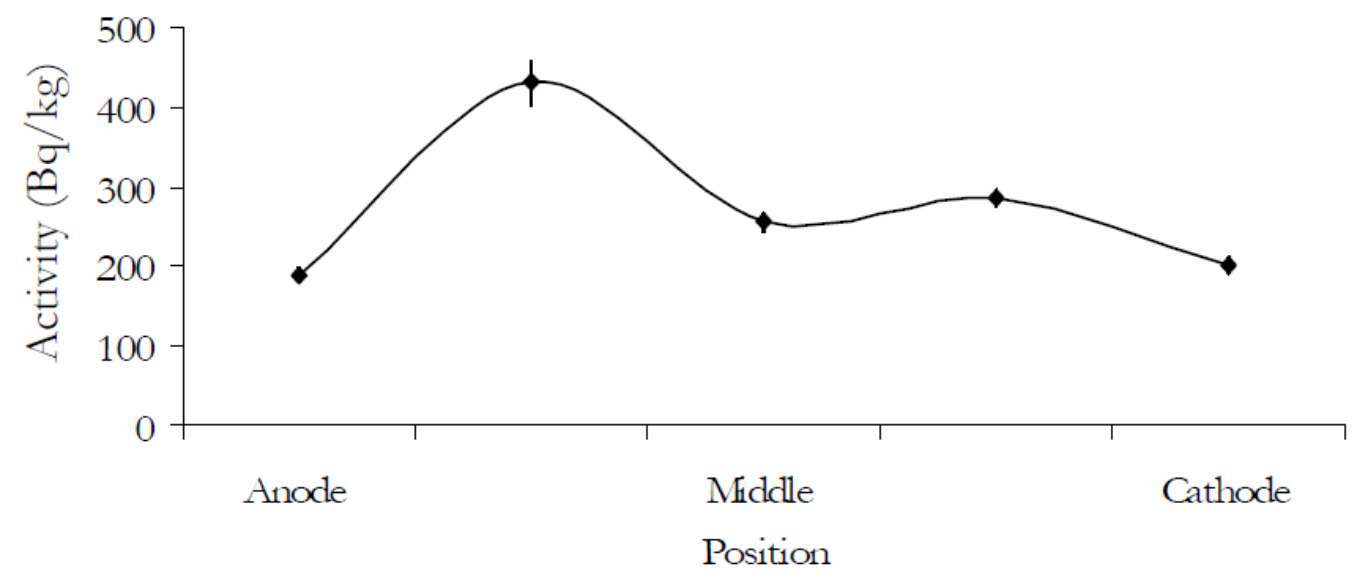

Figure 7 